\title{
Climatic Vagary and COVID-19 Pandemic: Influence on Livestock Production and Household Performance in South Western Nigeria
}

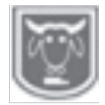

Sowande, O S., Yusuf, A O., Ayankoso, M T., Owolabi, A J. and Ajayi, T O.

Department of Animal Production and Health,

Federal University of Agriculture, Abeokuta, Nigeria

*Corresponding author: yusufao@funaab.edu.ng

Abstract

This research was aimed at investigating the recent climatic vagary on livestock production and household performance with the subsequent effect of COVID-19 pandemic in the SouthWestern Nigeria. Online survey was employed using a structured questionnaire as the test instrument. A total of 100 respondents was examined on how the recent climate change affect household performance, food consumption, farming (livestock production) with associated effects of COVID -19 pandemic. Data generated were subjected to descriptive statistics. Results depicted that $95.1 \%$ of respondents had tertiary education, $68.2 \%$ and $50.0 \%$ were male and self-employed, respectively. Majority (98.8\%) of the respondents were aware of the recent effect of climate change on livestock and $77.9 \%$ had been victims of it. About $56.5 \%$ kept livestock under intensive system. It was observed that $90.7 \%$ confirmed severe effect of climate change on availability of feed and the price. About $43.5 \%$ and $32.1 \%$ indicated that recent climate change had severe effects on level of production and mortality respectively. Report on household performance showed that $61.6 \%$ engaged in farming, in which livestock was $33.3 \%$ and mixed farming was $38.6 \%$. Severity of the effect of climate change was confirmed by $80 \%$ of the respondents with subsequent effect on price of food commodity (94\%), with family level of production (78.8\%) and cost of production (90.5\%). Pandemic decreased effect on the purchasing power of respondents $(54.7 \%)$ which equally affected the family food intake as confirmed by $73.6 \%$ and consequently affected the family protein consumption. It was observed that salary alone will not be enough to cope with future effect of pandemic but farming and side businesses are of vital values. These findings necessitate the adoption of agricultural production in every household to limit the effect of climatic change and financial crises posed by the pandemic. Conclusively, to curb the negative effect of climate change cum COVID-19 pandemic, agricultural practices should be encouraged among the youths and females to abate the impending food insecurity. Also, the rural agriculture should be encouraged through various agricultural aids to spur farmers' interest and boost their production potentials.

Keywords: Climate change, livestock and agricultural production, household performance, feed and feeding and COVID-19 pandemic

Vagary climatique et pandémie de COVID-19: influence sur la production animale et la performance des ménages dans le sud-ouest du Nigéria

\section{Résumé}

Cette recherche visait à enquêter sur les récents aléas climatiques sur la production animale et les performances des ménages avec l'effet consécutif de la pandémie COVID-19 dans le sud-ouest du Nigéria. L'enquête en ligne a été utilisée en utilisant un questionnaire structuré comme instrument de test. Un total de 100 répondants a été examiné sur la façon dont le récent changement climatique affecte les performances des ménages, la consommation alimentaire, l'agriculture (production animale) avec les effets associés de la pandémie COVID -19. Les données générées ont été soumises à des statistiques descriptives. Les 


\section{Climate vagary and COVID-19 Pandemic: Influence on livestock production}

résultats ont montré que 95,1\% des personnes interrogées avaient fait des études supérieures, 68,2\% et 50,0\% étaient des hommes et des travailleurs indépendants, respectivement. La majorité $(98,8 \%)$ des répondants étaient au courant de l'effet récent du changement climatique sur le bétail et 77,9\% en avaient été victimes. Environ $56,5 \%$ ont gardé le bétail dans un système intensif. Il a été observé que 90,7\% confirmaient un effet grave du changement climatique sur la disponibilité des aliments pour animaux et le prix. Environ $43,5 \%$ et $32,1 \%$ ont indiqué que les changements climatiques récents ont eu des effets graves sur le niveau de production et la mortalité respectivement. Le rapport sur la performance des ménages a montré que 61,6\% étaient engagés dans l'agriculture, dans laquelle le bétail était de 33,3\% et l'agriculture mixte était de 38,6\%. La gravité de l'effet du changement climatique a été confirmée par $80 \%$ des répondants avec un effet ultérieur sur le prix des denrées alimentaires (94\%), avec le niveau de production familial $(78,8 \%)$ et le coût de production (90,5\%). La pandémie a diminué l'effet sur le pouvoir d'achat des répondants $(54,7 \%)$, ce qui a également affecté l'apport alimentaire de la famille comme le confirme 73, $6 \%$ et a par conséquent affecté la consommation de protéines de la famille. Il a été observé que le salaire à lui seul ne suffira pas pour faire face aux effets futurs de la pandémie, mais l'agriculture et les activités annexes sont des valeurs vitales. Ces constats nécessitent l'adoption de la production agricole dans chaque ménage pour limiter les effets du changement climatique et des crises financières posés par la pandémie. En conclusion, pour freiner l'effet négatif du changement climatique et de la pandémie de COVID-19, les pratiques agricoles devraient être encouragées chez les jeunes et les femmes afin de réduire l'insécurité alimentaire imminente. En outre, l'agriculture rurale devrait être encouragée par diverses aides agricoles pour stimuler l'intérêt des agriculteurs et accroître leur potentiel de production.

Mots clés: Changement climatique, bétail et production agricole, performance des ménages, alimentation animale et pandémie COVID-19

\section{Introduction}

Climate has been the most important determinant of cropping seasons in nonirrigated farming system, and availability of some food/feedstuff for both man and animals. The greenhouse effect further worsens the situation thereby disrupting the normal known seasons through protracted dry period accompanied with increased temperature and excessive rainfall with accompanying flooding (Midgley et al., 2005; Ribot et al., 1996). In some places, the temperature extremes lead to heat stress which affects both crop performance and livestock productivity, while in some region the extended winter/coldest season leads to cold stress (Nardone et al., 2013; Rasoul et al., 2011). In Nigeria, the flooding that follows excessive rainfall affect the food crops/plant yield by either washing away both seeds and seedlings or cause leaching of nutrients, hence, affecting the overall plant yield. The temperature extremes have both direct and indirect effects on crop yield as most of the seeds and seedlings are dryoff thereby reducing the plant population, stunted growth of the surviving plants as well as reduction in the overall plant productivity. In extreme temperature, pasture plants, especially grasses become lignified, thereby reducing the quantity and quality of the available grasses (Dumont et al., 2015). The temperature further impairs pattern of appearance of both beneficial (pollinating) insects and non-beneficial organisms (pest and locust) (Yihdego et al., 2019). Furthermore, high environmental temperature leads to heat and nutritional stress in domestic animals (He et al., 2018; Das et al., 2016; Seijan et al.,2010;). The 


\section{Sowande, Yusuf, Ayankoso, Owolabi and Ajayi}

nutritional stress leadsto reduced growth rate and delay in attainment of puberty thereby affecting the reproduction potentials (Pradhan and Nakagoshi, 2008) as well as lower the overall productivity of the affected animals; This is further exacerbated by the effect of heat stress which leads to disruption of immune system of the affected animals. The immune system is broken down through the actions of reactive oxygen and nitrogen species causing oxidative stress, thus, impairing the normal physiological functions of the animals (Rahal et al., 2014). Consequently, climatic change through reduction in overall productivity of both plants and animals leads to food insecurity. Low yield from crop plants leads to competition between man animals for the available food/feedstuff, while the senescence pastures further worsen the situation through low productivity of livestock and other domestic animal species. Food insecurity sets in when the amount of food produced cannot meet the demands of growing population. This leads to food deficit, poor nutrition, malnutrition and subsequently food insecurity. With the recent COVID-19 pandemic, which resulted in the closure of most international borders and movement restrictions in some regions, further worsen the importation of food/feedstuff into low producing country like Nigeria. This research therefore seeks to identify the plurality effects of climate change and COVID-19 pandemic on livestock and food production as well as household performance in Nigeria.

\section{Methodology \\ Research instrument}

The instrument used in this research was a four-sectioned questionnaire. Section A of the questionnaire requested information on the demographic parameters of respondents; Section B sought to know the effect of climate change on livestock production; Section C focused on knowing the effect of climate change on household performance, food consumption and farming pattern while Section D sought to determine the effects of COVID-19 on household performance and food consumption.

\section{Method of data collection and analysis}

The research method used for this study was online survey and the sample size pulled was 100 respondents. The main data collection technique was through structured questionnaire targeting livestock farmers in South Western Nigeria to obtain qualitative data on effect of climate change on livestock production, effect of climate change on household performance, food consumption and farming pattern as well as the effects of COVID-19 on household performance and food consumption. The method of distribution of questionnaire was through online Google form link (https://forms.gle/PBkgDcqnSFKTWgMQ 6). Data generated were subjected to descriptive statistics using SPSS (2016) statistical software.

\section{Results and discussion \\ Demographic parameters}

About $95.1 \%$ of the respondents were educated farmers possessing tertiary education, $2.6 \%$ has no formal education, $2.3 \%$ of the respondents did not disclose their educational status while none of the respondents claimed to have primary and secondary education as their highest level of educational attainment (Figure 1). The highest number of learned individuals observed can be attributed to the mode of administration of questionnaire which is online. The $2.6 \%$ respondents with no formal education might have access the questionnaire through their wards that are educated. Sixty-five-point nine percent of the respondents $(65.9 \%)$ were married, $33.0 \%$ were single, while $1.1 \%$ did not disclose their marital status. None of the 
respondents were divorced and widowed (Figure 2). About $68.2 \%$ of the respondents were male and $30.7 \%$ were female while $1.1 \%$ did not disclose their sex. High number of male involvement justifies the reported major roles of men/male in Agricultural production. FAO (2010) stated that agriculture is underperforming because women do not have equal access to opportunities and resources needed to contribute more to food production. This showed that sustainable food production cannot be attained with less involvement of women in livestock and agricultural activities. Half (50.0\%) of the total number of respondents were self-employed, $38.6 \%$ were civil servants, $10.2 \%$ were unemployed while $1.1 \%$ were silent on their employment status. (Figure 3). From the foregoing, livestock production in particular and agriculture generally seems to be providing succor both for the unemployed, employed and underemployed populations in the research area. About $39.8 \%$ of the respondents had less than 5years of farming experience, $34.1 \%$ had 10years of experience, $13.6 \%$ had between 11 - and 20-years farming experience while $5.7 \%$ did not disclose their farming experience. This result showed that a higher proportion of the respondents are recent entrants into the agricultural activities especially in the last $5-10$ years. This implies that government efforts in returning to livestock production and agriculture through the agricultural transformation agenda and more recently, agricultural promotion policy, are yielding positive results.

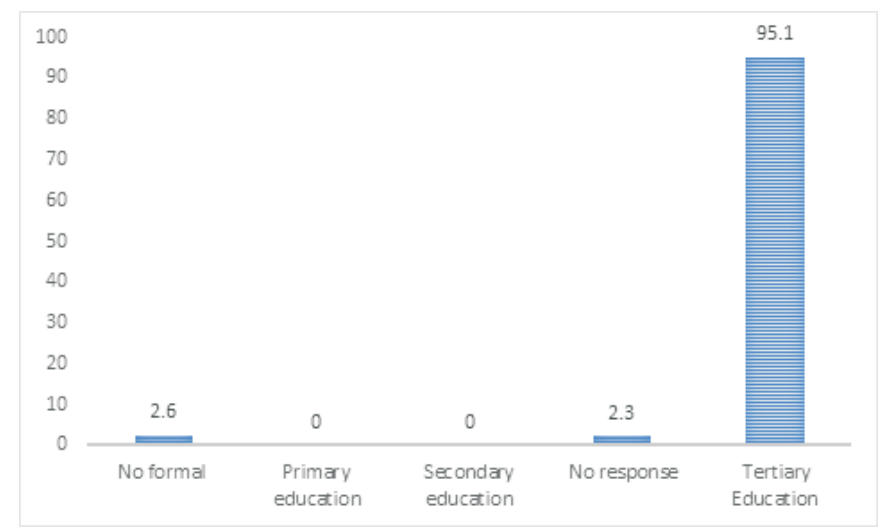

Figure 1. Academic status of respondent

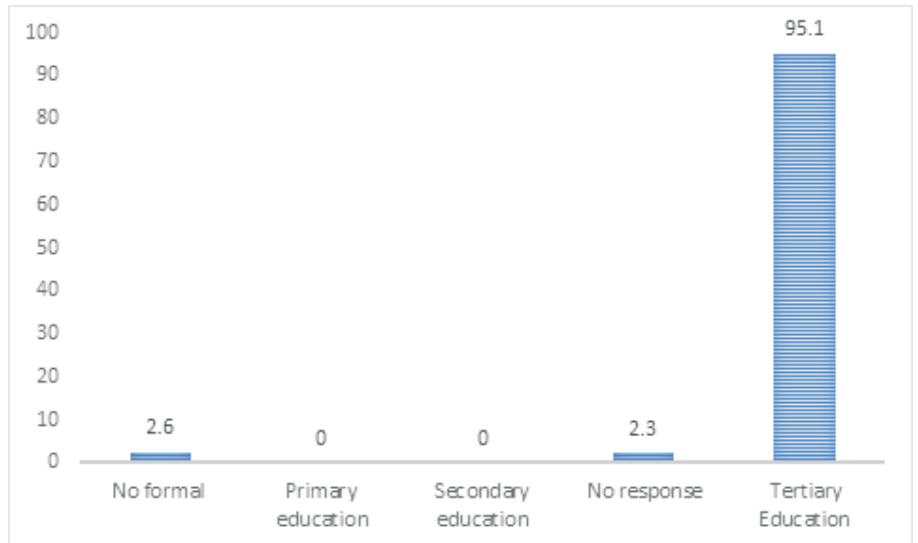

Figure 2: Marital status of respondent 


\section{Sowande, Yusuf, Ayankoso, Owolabi and Ajayi}

Climate change and livestock production Majority (98.8\%) of the respondents were aware of the recent trends of climatic changes and its associated effects on livestock production (Table 1) because they would have had the knowledge about the recent climatic change through weather forecast on mobile phones, social media interactions, electronic media agricultural extension activities, personal reading of news items and possibly based of their years of experience in livestock production activities. As documented in this study more than half of the respondents had farming experience of $1-10$ years. This corroborated the report of Ado et al. (2019) which stated that $84.4 \%$ of sampled respondents were aware of detrimental effect of weather changes in their climate awareness research. In addition, Ajayi (2014) documented that farmers at some point in their farming years had access to media mostly radio as source of awareness of events related to them. Results by Shukla et al. (2016); and Mandleni and Anim (2011) further corroborated the results of this present study where they depicted that $85 \%$ of their respondent were aware of weather changes over time. Climatic change phenomenon has been a bar to favorable livestock and agricultural production in Africa, and this is further worsened by the recent increase in temperature and excessive rainfall (Dumont et al., 2015). This justifies the reported seventy-seven-point nine percent $(77.9 \%)$ of the respondents that had experienced an outbreak of disease either due to heat or cold stress. In poultry production the heat stress has been the most limiting factor to optimum growth and productivity as it affects the immune function of this class of animals thereby affecting their overall performance. Monogastric animals (chickens) were kept in large numbers $(59.5 \%)$ compared to other livestock, with ruminant animal production taking about
$15.5 \%$ and fisheries $4.8 \%$ among the respondents. Most of the respondents employed intensive system (56.5\%) Only $2.4 \%$ keep their animals in extensive system while $10.6 \%$ employed semi-intensive system. Higher number of monogastric animals kept and the intensive production system employed further justify the reported heat stress experienced by the farmers. Consequently, high temperature extremes with high relative humidity are detrimental to both commercial crop and livestock production (Morrison 1983). Adopting intensive production system is premised on the pressure on livestock production to meet the increasing demand for animal protein consequent upon increasing population. Recent report (Rust, 2019) indicated that intensive livestock production is favoured compared to extensive method and that monogastric production (poultry and pig) would have more value than ruminant livestock production under the current climate change scenario. It was discovered that the fluctuation in climatic pattern greatly affect the availability of forage and other feed ingredients with attendant increase in price of feed and feed ingredients for the livestock as $96.5 \%$ of the respondents attested to it. The scarcity of feed resource supported the earlier report that during the period of temperature extremes, pasture plants, especially grasses are lignified, thereby reducing the quantity and quality of the available grasses (Dumont et al., 2015). During this period, the price of feed increased than expected as confirmed by $91.6 \%$ of the respondents which resulted in high cost of production as indicated by $90.7 \%$ of the respondents. About $54.4 \%$ (severe) and $20.3 \%$ (very severe) of the respondents attested that availability of feed and feed ingredients was negatively and severely affected by the weather pattern (Figure 4). The increase in price reported was occasion by the scarcity of feed 
resource and an attempt by farmers to feed their animals at all cost compelled to buy feed at exorbitant prices. This is further exacerbated through the competition between man and animals for the scarce food/feed resource (Wilkinson and Lee,
2018). Polaski (2008) further stated that incidence of drought, high demand owing to increase in household income and government neglects in some developing countries are part of mixed factors affecting the price of feed resources in livestock production.

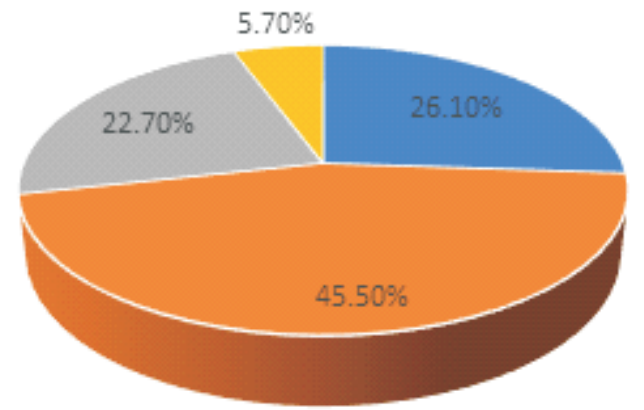

- Very severe

- Severe

- Moderate

- High

Figure 4: Climate versus feed ingredient supply pattern

For all classes of livestock, $42 \%$ of the respondents confirmed experiencing disease outbreak mostly during the dry season while $34.9 \%$ of the respondents documented that their experience of health challenges was at its peak during the wet season. Other respondents (20.5\%) reported the case of health impairment during both wet and dry seasons. The proportion of respondents who agreed that climatic change occasionally affected their livestock performance was $(51.8 \%)$ while $40 \%$ of the respondents confirmed that climatic change regularly affect the performance of their animals. The impact of weather has been reported to greatly affect agricultural production. In relation to livestock production, the direct effect of climate extremes includes reduced animal production efficiency, reproductive performance, milk yield and disruption in physiological performance, while the indirect effect of livestock are through reductions or non-availability of feed and water resources (Nardone et al.,2010). This further confirms the results of this study where the respondent reported that climatic change resulted in unavailability of feed.
Inadequate nourishment of animals would predispose them to various health challenges, anorexia sets in, hence the animal would become emaciated. Consequently, the animal growth and reproductive performance will be greatly hindered. As confirmed by $79.1 \%$ of the respondents, feed has the highest influence on cost of production compare to health $(15.1 \%)$ and housing management $(2.3 \%)$. Feed/feeding was the major limiting factor to livestock production, taking about $70 \%$ of the cost of production. With the recent weather extremes and inadequate rainfall, there is the tendency that more livestock farmers would be affected as price of feed and feed ingredients continue to increase with possibility of some of the livestock farms shutting down. Various health challenges experienced by livestock farmers also impact on cost of production; research documented that it is not as high in terms feed cost value (Thornton, 2010; NRC, 2003). Most of the respondents $(43.5 \%)$ established that the level of their animal productivity was severely affected by the recent climatic change while $38.8 \%$ of the respondents reported a mild effect of 


\section{Sowande, Yusuf, Ayankoso, Owolabi and Ajayi}

climactic change on the level of animal productivity. Mortality rate was reported to be high by $32.1 \%$ of the respondents while $42.3 \%$ reported mild mortality rate as a result of climatic vagary. Further to this, ppastoralists and livestock farmers in tropical and sub-tropical Africa have related fluctuations in temperature and rainfall patterns with unavailability of feed sources, increased animal mortality and reduced herd or flock sizes (Liverpool-Tasie et al., 2019).

Climatic change, household performance, food consumption and farming interest

Of the 100 respondents, $61.6 \%$ were engaged in farming (Table 2). In order to boost household food production, there is need for several individuals to engage in farming activities be it crop or livestock production so as to increase the nutritional intake of the family. It was documented that the most rural dwellers cannot meet their nutrient requirements (FAO, 2020). This would further increase health challenges, reproductive failure and the incidence of child mortality in most rural community. The engagement of several farmers in farming would abate this food insecurity occasioned by the prevailing climatic changes (FAO, 2020). Thirty-three-point three percent $(33.3 \%)$ of the respondents were involved in livestock production $28.1 \%$ in crop production while $38.6 \%$ of the respondents were involved in mixed farming. The variation in agricultural practices is dependent on farmers' location as occasioned by prevailing weather condition of certain environments. This would be further determined by interest and/or expertise of the farmers. About 80\% of the respondents confirmed that the climatic change had severe effect on price of food commodities. Approximately 60\% of the respondent confirmed that the increase in food prices had severe effects on the quantity and quality of food consumed. This is line with the previous reports (FAO,
1993; Zhu and Zhong2005) that established significant effect of food prices on family nutritional welfare, which invariably affect the quality and quantity of food consumption. Rise in price of food commodities can be linked to complex of mixed factors (Nardone et al., 2010). However, as the effect of climatic changes deepens, it would further disrupt the rainfall pattern with associated increased temperature in various zones. This would subsequently affect food/feed supply as earlier mentioned (Nardone et al., 2010; NRC 2003). Of all the produce obtained from family farm, $60 \%$ of the produce contributed to family feeding while $40 \%$ was offered for sale. Family level of production $(78.8 \%)$ and cost of production $(90.5 \%)$ were affected by the effect of climatic change.

Household performance and food consumption as affected by COVID-19 pandemic

Fifty-four-point seven percent $(54.7 \%)$ of the respondents attested that family purchasing power decreased due to the effect of COVID-19 pandemic (Table 3). Some family head lost their well-paid jobs due to the new-normal working from home rule as occasioned by the pandemic. Loss of job or payable employment led to reduction in family income with attendant decrease in family purchasing power. This could be attributed to massive economic shock posed by the COVID -19 pandemic through business interruptions and shutdowns arising from social-distancing measures (Khan et al., 2019; Guddad and Terdal, 2020). Family food intake was negatively affected $(73.6 \%$ of respondents) while $65.5 \%$ of the respondents indicated that the pandemic affected their animal protein intake which further negatively affected meeting the family nutritional requirements (67.8\% of respondents). Very large proportion $(82.6 \%)$ of the respondents affirmed that the pandemic negatively 
Climate vagary and COVID-19 Pandemic: Influence on livestock production

Table 1: Climatic Change and its associated effect on Livestock Production

\begin{tabular}{|c|c|c|c|c|}
\hline \multirow{3}{*}{$\begin{array}{l}\text { Parameters } \\
\text { Types of livestock kept }\end{array}$} & Monogastric & Ruminants & Fisheries & Others \\
\hline & $59,50 \%$ & $15,50 \%$ & $4,80 \%$ & $20,20 \%$ \\
\hline & Intensive & $\begin{array}{l}\text { Semi- } \\
\text { intensive }\end{array}$ & $\begin{array}{l}\text { Backyard } \\
\text { farming }\end{array}$ & Extensive \\
\hline \multirow[t]{2}{*}{ System of production employed } & $56,50 \%$ & $10,60 \%$ & $25,90 \%$ & $2,40 \%$ \\
\hline & Yes & No & & \\
\hline \multirow[t]{2}{*}{$\begin{array}{l}\text { Climate change vs cold or heat stress } \\
\text { occurrence } \\
\text { climate change vs feed/food availability } \\
\text { climate change vs feed/food cost } \\
\text { climate change vs cost of production }\end{array}$} & $\begin{array}{l}77,90 \% \\
96,50 \% \\
91,60 \% \\
90,70 \%\end{array}$ & $\begin{array}{l}20,10 \% \\
3,50 \% \\
9,40 \% \\
9,30 \%\end{array}$ & & \\
\hline & Dry season & $\begin{array}{l}\text { Wet } \\
\text { season }\end{array}$ & $\begin{array}{l}\text { All of the } \\
\text { above }\end{array}$ & $\begin{array}{l}\text { None of the } \\
\text { above }\end{array}$ \\
\hline $\begin{array}{l}\text { Climate vs disease invasion in livestock } \\
\text { production }\end{array}$ & $\begin{array}{l}42 \% \\
\text { Occasionally }\end{array}$ & $\begin{array}{l}35,20 \% \\
\text { Regularly }\end{array}$ & $\begin{array}{l}20,50 \% \\
\text { Never }\end{array}$ & $\begin{array}{l}2,30 \% \\
\text { Indifferent }\end{array}$ \\
\hline Climate change vs performance of livestock & $\begin{array}{l}51.8 \% \\
\text { High }\end{array}$ & $\begin{array}{l}40 \% \\
\text { Mild }\end{array}$ & $\begin{array}{l}4,60 \% \\
\text { No response }\end{array}$ & $3.6 \%$ \\
\hline Climate change vs mortality & $32,10 \%$ & $42.30 \%$ & & \\
\hline
\end{tabular}

Table 2: Climatic change versus household performance as depicted by the respondents

\begin{tabular}{llll}
\hline Parameters & Yes & No & \\
\hline Household vs farming & $61.6 \%$ & $38.40 \%$ & \\
Household vs Agricultural Production & Livestock & Crop & Mixed \\
& $28.1 \%$ & $38.6 \%$ & 33.3 \\
Climate change vs food prices & High & Low & \\
Prices vs food consumption & $80 \%$ & $20 \%$ & \\
& High & Low & \\
Household Production vs Use & $60 \%$ & $40 \%$ & \\
& Consumption & Sales \\
Household vs Production level & $60 \%$ & $40 \%$ \\
Household vs Production Cost & High & Low \\
\hline
\end{tabular}

affected the family business and income. Effect of the pandemic on the prices of food commodities as stated by $98.9 \%$ of respondents indicated that the COVID-19 pandemic raised the prices of food commodities. This was the consequent effect of the pandemic and the accompanying restrictions which obstructed all stages of the food supply chain, including production, distribution, processing, and consumption (Siche, 2020, Torero, 2020), and damage of perishable agricultural commodities such as meat and vegetables (Nicola et al., 2020). Similar results were also documented by Kansiime et al. (2021) who reported change in household dietary patterns in response to the COVID-19 outbreak by consuming less diverse diets, skipping meals, and reducing portions of food consumed. The results 


\section{Sowande, Yusuf, Ayankoso, Owolabi and Ajayi}

point to the detrimental impacts of the pandemic on household food and nutrition security. To minimize the effect of the pandemic on the family, about $49.4 \%$ of the respondents engaged in side businesses as a coping strategy during the pandemic while. $18.8 \%$. $17.6 \%$ and $14.1 \%$ of the respondents, respectively depended on loans and gifts from families and friends as a coping strategy. To survive the effect of COVID-19 pandemic lockdown, 35.3\% of the respondents depended on salary + side business, while $32.9 \%$ depended solely on business and $16.5 \%$ solely depended on salary. Others depended on farming $(1.2 \%)$. spouses $(1.2 \%)$. and pension $(1.2 \%)$ amongst others as a way out of hunger. After the ease of pandemic lockdown, similar trend of survival was observed by the respondents with $44 \%$ of them depending on salary + side business, $39.3 \%$ only on business and $13.1 \%$ on salary alone. About $88.1 \%$ engaged in agricultural production to aid food sustainability during the pandemic. Of these, $32.9 \%$ engaged in backyard farming. $23.7 \%$ on livestock production. $22.4 \%$ on crop production and $21.1 \%$ engaged in mixed farming. With the COVID-19 pandemic causing delays in payments of wages and salaries as well as job losses, the results of this study show majority of the respondents involved in farming, side businesses as well as receiving gifts and taking loans as a means of coping with income loss as a result of the lockdown imposed by the pandemic. These findings are similar to those reported in Kenya and Uganda (Kansiime et al., 2021) where obtaining credit or in-kind support from family and friends and selling of assets were documented as coping strategies. The report further opined that savings/loans became an important resource for smoothing household consumption and that participating in savings groups was significantly associated with a reduction in the perceived effect of COVID-19 on income sources. Various studies have also found that households in Kenya and Uganda as well as other developing countries rely on similar coping strategies to buffer the effects of unexpected income shocks during pandemic (Amendah et al., 2014, Mawejje, 2019, Opiyo et al., 2015, Yilma et al., 2014). About $51.8 \%$ of respondents experienced low level of availability of feed/foodstuffs while about $48.2 \%$ had high availability of feed/foodstuffs. Eighty percent $(80 \%)$ of respondents reported that transportation of feed/food items for both man and animals was negatively and highly affected by the pandemic lockdown while about 20\% claimed low effect of transportation. This further affected the prices of commodities in the market with about $94.1 \%$ of respondents attesting to high prices of food commodities. About $47.1 \%$ of respondents predicted that the pandemic would 1 have a high negative effect on the availability of food/feedstuffs in the future while $52.9 \%$ predicted otherwise. About 56.5\% also attested that the pandemic affected the quantity and quality of food consumed at home while $11.8 \%$ claimed otherwise. The reduced food/feed availability was based on the hardship posed by the pandemic through disruption of food supply, movement restriction, food spoilage among others (Nicola et al., 2020). On a general note, mmajor natural occurrences (disaster/pandemic) can or do have severe negative short-run economic impacts. They also appear to have adverse and longer-term consequences on economic growth, development and poverty rate (Benson and Clay, 2003). 
Climate vagary and COVID-19 Pandemic: Influence on livestock production

Table 3: Household performance as affected by COVID-19 pandemic

\begin{tabular}{lllll}
\hline Parameters & High & Low & & \\
\cline { 1 - 2 } & $45.3 \%$ & $54.7 \%$ & & \\
Pandemic vs food intake & $26.4 \%$ & $73.6 \%$ & \\
Pandemic vs protein intake & $34.5 \%$ & $65.5 \%$ & \\
Pandemic vs nutritional requirements & $32.2 \%$ & $67.8 \%$ & \\
Pandemic vs family income & $17.4 \%$ & $82.6 \%$ & \\
Pandemic vs food prices & $98.9 \%$ & $1.1 \%$ & & \\
Pandemic vs food availability & $48.2 \%$ & $51.8 \%$ & & \\
Pandemic vs transportation of food & $80 \%$ & $20 \%$ & & \\
Pandemic vs future food availability & $47.1 \%$ & $52.9 \%$ & & \\
& Side business & Farming & Gifts & Loans \\
Pandemic vs coping strategy & $49.4 \%$ & $18.8 \%$ & $14.1 \%$ & $17.6 \%$ \\
& salary + side business & Business & salary & others \\
Pandemic vs income & $35.3 \%$ & $32.9 \%$ & $16.5 \%$ & $15.3 \%$ \\
Post pandemic vs income & $44.0 \%$ & $39.3 \%$ & $13.1 \%$ & $3.6 \%$ \\
& Yes & No & & \\
Pandemic vs farming & $88.1 \%$ & $11.9 \%$ & & \\
& Livestock & Crop & Mixed & Backyard \\
Pandemic vs agricultural production & $23.7 \%$ & $22.4 \%$ & $21.1 \%$ & $32.9 \%$ \\
\hline
\end{tabular}

\section{Conclusion}

The study showed that the recent climatic phenomenon is hitting hard on various forms of agricultural practices particularly, livestock production which was further worsened by the COVID-19 pandemic leading to reduced livestock productivity, crop failure, loss of jobs, hike in food prices, food insecurity and increased poverty rate. In this case, efforts should be intensified by government and other stakeholders involved in agricultural policies to put in place policies that would promote adoption of mitigation strategies as well as modification of livestock and crop production systems to suit the changing climate, encourage youths and adults to engage more in all forms of agriculture (both rural and urban farming) to cope with increasing demand for food especially animal protein and boost agricultural production through implementation of different forms of agricultural aids.

\section{References}

Ajayi, J. 2014. Awareness of climate change and implications for attaining the Millennium
Development Goals (MDGs) in Niger Delta Region of Nigeria. Agris on-line Papers in Economics and Informatics. 6, 3.

Amendah, D. D., Buigut, $S$ and Mohamed, S. 2014. Coping strategies among urbanpoor: Evidence from Nairobi, Kenya. PLoS ONE. 9(1) e83428.

Benson, $\mathrm{C}$ and Clay, E., 2003. Economic and Financial Impacts of Natural Disasters: an assessment of their effects and options for mitigation: synthesis report. London: Overseas Development Institute (ODI).

Das, R., Sailo, L., Verma, N., Bharti, P and Saikia, J. 2016. Impact of heat stress on health and performance of dairy animals: A review. Veterinary world.9(3), p.260.

Dumont, B., Andueza, D., Niderkorn, V., Lüscher, A., Porqueddu, $C$ and Picon-Cochard, C. 2015. A meta-analysis of climate change effects on forage quality in grasslands: specificities of mountain and Mediterranean areas. Grass and Forage Science. 70(2), 
pp.239-254.

FAO 2020. The state of food security and nutrition in the world 2020: transforming food systems for affordable healthy diets.

Guddad, M.S. and Terdal, M.V.S., 2020. IMPACT OF COVID-19 ON I N D I A N E C O N O M Y. Seshadripuram Journal of Social Sciences (SJSS). 2581, p.145.

He, S. P., Arowolo, M. A., Medrano, R. F., Li, S., Yu, Q. F., Chen, J. Y and He, J.H. 2018. Impact of heat stress and nutritional interventions on poultry production. World's Poultry Science Journal. 74(4), pp.647-664.

Kansiime, M. K., Tambo, J. A., Mugambi, I., Bundi, M., Kara, A and Owuor, C. 2021. COVID-19 implications on household income and food security in Kenya and Uganda: Findings from a rapid assessment. World development. 137, p.105199.

Khan, N., Fahad, S., Naushad, $M$ and Faisal, S. 2020. COVID-2019 Locked down Effects on Oil Prices and Its Effects on the World Economy. Available at SSRN 3588810 .

Liverpool-Tasie, L. S. O., Sanou, $A$ and Tambo, J.A. 2019. Climate change adaptation among poultry farmers: evidence from Nigeria. Climatic Change. 157(3), 527-544.

Mandleni, B and Anim, F. 2011. Perceptions of cattle and sheep farmers on climate change and adaptation in the Eastern Cape Province of South Africa. Journal of Human Ecology. 34, 107-112.

Mawejje, J. 2019. Financial inclusion, shocks and coping strategies: Surveyevidence from Uganda. African Journal of Economic and $\begin{array}{llllllllll}M & a & n & a & g & e & m & e & n & t\end{array}$
Studies.https://doi.org/10.1108/AJ EMS-10-2018-0325.

Midgley, G. F., Chapman, R. A., Hewitson, B., Johnston, P., De Wit, M., Ziervogel, G., Mukheibir, P., Van Niekerk, L., Tadross, M., Van Wilgen, B. W and Kgope, B. 2005. A status quo, vulnerability and adaptation assessment of the physical and socio-economic effects of climate change in the Western Cape.

Morrison, S. R. 1983. Ruminant heat stress: effect on production and means of alleviation. Journal of animal science. 57 (6): 1594-1600.

Nardone, A., Ronchi, B., Lacetera, N., Ranieri, M. S and Bernabucci, U. 2010. Effects of climate changes on animal production and sustainability of livestock systems. Livestock Science. 130(1-3), 57-69.

Nardone, A., Ronchi, B., Lacetera, N., Ranieri, M.S and Bernabucci, U., 2010. Effects of climate changes on animal production and sustainability of livestock systems. Livestock Science. 130(1-3), pp.5769.

National Research Council. 2003. Air emissions from animal feeding operations: Current knowledge, future needs.

Opiyo, F., Wasonga, O., Nyangito, M., Schilling, $J$ and Munang, R. 2015. Droughtadaptationand coping strategies among the Turkana pastoralists of northernKenya. International Journal ofDisaster Risk Science. 6(3), 295-309.

Polaski, S 2008. Food prices, poverty, and small-scale farmers: Getting the global trade regime right. In Proceedings of the meeting on policies for the effective management of sustained food 
price increases.

Pradhan, R and Nakagoshi, N. 2008. Reproductive disorders in cattle due to nutritional status. Journal of International development and cooperation. 14(1), pp.45-66.

Rahal, A., Kumar, A., Singh, V., Yadav, B., Tiwari, R., Chakraborty, S and Dhama, K. 2014. Oxidative stress, prooxidants, and antioxidants: the interplay. BioMed research international, 2014.

Rasul, G., Chaudhry, Q. Z., Mahmood, A and Hyder, K.W. 2011. Effect of temperature rise on crop growth and productivity. Pak. J. Meteorol, 8(15), pp.53-62.

Ribot, J. C., Najam, A and Watson, G. 1996. Climate variation, vulnerability and sustainable development in the semi-arid tropics (pp. 13-54). Cambridge University Press, Cambridge, United Kingdom and New York, NY, USA.

Rust, J. M. 2019. The impact of climate change on extensive and intensive livestock production systems. Animal Frontiers 9(1): 20 - 25

Sejian, V., Maurya, V.P and Naqvi, S.M. 2010. Adaptability and growth of Malpura ewes subjected to thermal and nutritional stress. Tropical Animal Health and Production. 42(8), pp.1763-1770.

Seo, S. N and Mendelsohn, R. 2006. Climate change impacts on animal husbandry in Africa: A Ricardian analysis. CEEPA Discussion Paper No. 9, Centre for Environmental Economics and Policy in Africa, University of Pretoria, South Africa.

Shukla, G., Kumar, A., Pala, N. A and Chakravarty, S. 2016. Farmers perception and awareness of climate change: a case study from
Kanchandzonga Biosphere Reserve, India. Environment, Development and Sustainability, 18, 1167-1176.

Smith, B., McNabb, D and Smithers, J. 1996. Agricultural adaptation to climatic variation. Climate change 43, 7-29

Thornton, P. K. 2010. Livestock production: recent trends, future prospects. Philosophical Transactions of the Royal Society B: Biological Sciences. 365(1554), 2853-2867.

Thornton, P., Herrero, M., Freeman, A., Mwai, O., Rege, E., Jones, $P$ and M c D e r m ot t , J . 2007 . Vulnerability, climate change and livestock - Research opportunities and challenges for poverty alleviation. SAT eJournal 4 (1), 123.

Yihdego, Y., Salem, H. S. and Muh a m med, H.H. 2019. Agricultural pest management policies during drought: case studies in Australia and the State of Palestine. Natural Hazards Review.20(1), p.05018010.

Yilma, Z., Mebratie, A., Sparrow, R., Abebaw, D., Dekker, M., Alemu, $G$ and Bedi, A. S.2014. Coping with shocks in rural Ethiopia. Journal of Development Studies. 50(7), 1009-1024.

Zhu, J and Zhong, F. N. 2005. Regional disparity of food consumption in rural China and policy choose. Rural Economy. 2, 46-48.

Received $2^{\text {th }}$ December, 2020 Accepted $5^{\text {th }}$ February, 2021 